\title{
The effects of irradiance and photoperiod on the growth rate of three freshwater green algae isolated from a eutrophic lake
}

\author{
Radia Bouterfas $^{1, *}$, Mouhssine Belkoura ${ }^{2}$, AlainDauta ${ }^{3}$ \\ 1 Département de Biologie, Faculté des Sciences et Techniques, Université Cadi Ayyad , B.P. 549, 40000 Guéliz, \\ Marrakech, Maroc. Fax (212) (0) 24433170. \\ ${ }^{2}$ Equipe Biotechnologie Algale, Laboratoire de Physiologie Végétale, Faculté des Sciences Semlalia, Avenue \\ Prince Moulay Abdellah, B.P. S2390, 40000, Marrakech, Maroc. \\ 3 Centre d'Ecologie des Systèmes Aquatiques Continentaux, UMR C.5576 CNRS, Université Paul Sabatier, 118, \\ route de Narbonne, 31062 Toulouse Cedex, France.
}

* Corresponding author: bouterfas@fstg-marrakech.ac.ma

\begin{abstract}
The effects of irradiance and photoperiod on the growth rate of three freshwater green algae isolated from a eutrophic lake

In order to optimise algal growth in mass culture systems, the effect of irradiance and photoperiod on the growth rate of three freshwater green algae isolated from an eutrophic lake (Selenastrum minutum, Coelastrum microporum f. astroidea and Cosmarium subprotumidum) were studied in non axenic batch cultures, under non-nutrient limited conditions. Experiments were performed to determine a specific growth rate $(\mu \max )$ and optimum light (Iopt) over a wide range of light intensities (30 to $456 \mu \mathrm{mol} \mathrm{m}^{2} \mathrm{~s}^{-1}$ ) at a temperature of $30^{\circ} \mathrm{C}$, using a $15 / 9$ (light/dark) photoperiod cycle. The maximum growth rates and optimum light intensities were $1.55 \mathrm{~d}^{-1}$ and $365 \mu \mathrm{mol} \mathrm{m}^{-2} \mathrm{~s}^{-1}$ for Selenastrum minutum, $1.59 \mathrm{~d}^{-1}$ and $390 \mu \mathrm{mol} \mathrm{m}^{-2} \mathrm{~s}^{-1}$ for Coelastrum microporum f. astroidea $0.88 \mathrm{~d}^{-1}$ and $360 \mu \mathrm{mol} \mathrm{m}^{-2} \mathrm{~s}^{-1}$ for Cosmarium subprotumidum. The photoperiod's effect was determined at $30^{\circ} \mathrm{C}$ and an incident light of $300 \mu \mathrm{mol} \mathrm{m}^{-2} \mathrm{~s}^{-1}$, under various light:dark cycles. The experimental values fitted by models of Belkoura et Dauta (1992) indicate an increase in the growth rate versus day length with a maximum at continuous light $\left(1.84 \mathrm{~d}^{-1}\right.$ for Selenastrum minutum, $1.72 \mathrm{~d}^{-1}$ for Coelastrum microporum $f$. astroidea, $0.88 \mathrm{~d}^{-1}$ for Cosmarium subprotumidum). However these experiments don't take into account the accumulated light intensities received by each culture (period of incubation: 24 hours). It was, therefore, not possible to independently appraise the real effect of the lengthened irradiance exposure. So more experiments were carried out, where all cultures under different (light/dark) photoperiod cycles at $30^{\circ} \mathrm{C}$ received the same cumulated irradiance $\left(8.6 \mathrm{~mol} \mathrm{~m}^{-2} \mathrm{~d}^{-1}\right)$. The results showed that the growth rate is not constant but increased with day length with a maximum at continuous light. These results confirm the real effect of photoperiod on the microalgae growth rate.
\end{abstract}

Key words: Green algae, growth rate, irradiance, photoperiod.

\section{RESUMEN}

Los efectos de la irradiancia y el fotoperiodo en la tasa de crecimiento de tres algas verdes aisladas de un lago eutrófico

Con objeto de optimizar el crecimiento algal en cultivos de producción masiva, se han estudiado, en cultivos no estériles y sin limitación de nutrientes, el efecto de la irradiancia y el fotoperiodo sobre la tasa de crecimiento en tres algas de agua dulce de un lago eutrófico (Selenastrum minutum, Coelastrum microporum f. astroidea and Cosmarium subprotumidum). Los experimentos fueron diseñados para determinar una tasa de crecimiento específica ( $\mu \max$ ) y un óptimo de luz (Iopt) en un amplio rango de intensidades de luz (30 a $456 \mathrm{\mu mol} \mathrm{m}^{-2} \mathrm{~s}^{-1}$ ), a $30^{\circ} \mathrm{C}$ de temperatura y utilizando ciclo de fotoperiodo 15/9 (luz/oscuridad). Las tasas máximas de crecimiento y las intensidades de luz óptimas fueron $1.55 \mathrm{dia}^{-1}$ y $365 \mathrm{\mu mol} \mathrm{m}^{-2} \mathrm{~s}^{-1}$ para Selenastrum minutum, $1.59 \mathrm{dia}^{-1}$ y $390 \mathrm{\mu mol} \mathrm{m}^{-2} \mathrm{~s}^{-1}$ para Coelastrum microporum f. astroidea y $0.88 \mathrm{dí}^{-1}$ y $360 \mu \mathrm{mol}$ $\mathrm{m}^{-2} \mathrm{~s}^{-1}$ para Cosmarium subprotumidum. El efecto del fotoperiodo se determino a $30^{\circ} \mathrm{C}$ y luz incidente de $300 \mu \mathrm{mol} \mathrm{m} \mathrm{m}^{-2}$ $s^{-1}$, bajo varios ciclos luz:oscuridad. Los valores experimentales se ajustaron mediante modelos Belkoura y Dauta (1992) $e$ indican un incremento en la tasa de crecimiento en relación con la duración del día, con un máximo a luz continua (1.84 día ${ }^{-1}$ 
for Selenastrum minutum, $1.72 \mathrm{dia}^{-1}$ for Coelastrum microporum f. astroidea, $0.88 \mathrm{dia}^{-1}$ for Cosmarium subprotumidum). No obstante, estos experimentos no tuvieron en cuenta las intensidades de luz acumulada recibidas por cada cultivo (periodo de incubación de 24 horas). Además, no fue posible apreciar de forma independiente el efecto real del tiempo de exposición de la irradiancia. Por ello se realizaron otros experimentos en los que todos los cultivos bajo diferentes ciclos de fotoperiodo (luz/oscuridad) y a $30^{\circ} \mathrm{C}$, recibieron la misma irradiancia acumulada $\left(8.6 \mathrm{~mol} \mathrm{~m}^{-2} \mathrm{dia}^{-1}\right)$. Los resultados confirmaron el efecto real del fotoperiodo sobre la tasa de crecimiento de las microalgas.

Palabras clave: Algas verdes, tasa de crecimiento, irradiancia, fotoperiodo.

\section{INTRODUCTION}

The culture of microalgae requires a rigorous control of all growth factors: nutrients, $\mathrm{pH}$, and temperature, concentration of $\mathrm{CO}_{2}, \mathrm{O}_{2}$, and light (Morris, 1981). The optimisation of the yield is the main factor in mass culture technology of microalgae. Thus, it is necessary to understand the behaviour of algal species under different environmental factors that determine the different growth parameters. The study of the interactions between these factors and growth modelling parameters allows finding the optimal conditions for selected species in large-scale productivity.

Overall, the growth of microalgal populations depends on three abiotic factors: available light, temperature, and level of nutrients such as nitrogen, phosphorus, and silicate (for diatoms). Among these factors, the light that directly influences photosynthesis mechanism is an important factor in defining optimal conditions for the culture (Falkowski et al., 1985). In the presence of non-limiting nutriments, the efficiency of microalgal culture remained controlled mainly by the intensity of light and temperature.

In addition to temperature and light intensity that are among the main factors acting on the biomass productivity in large-scale microalgae cultures (Richmond, 1986a; De la Noüe $\&$ De Pauw, 1988), day length is the determinant factor on the microalgae development. Indeed, the day length influences the circadian rhythm of photosynthesis, respiration (Piquemal, 1990), cellular division (Hobson et al., 1979), and the growth rate (Redalje \& Laws, 1983). Moreover, this factor has also an affect on the enzymatic activities (Hobson et al.,

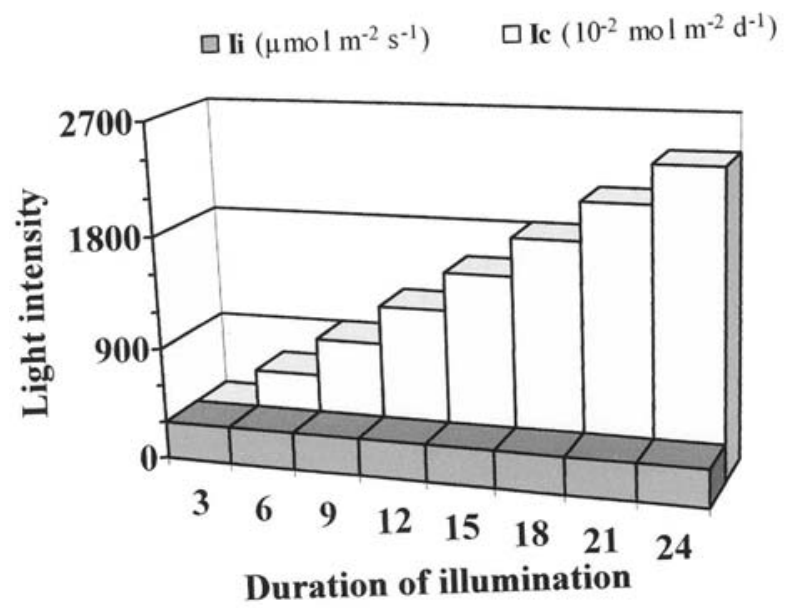

Figure 1. Variation of accumulated irradiance (Ic) in relation to the duration of illumination for a constant incident irradiance (Ii). Variación de la irradiancia acumulada (IC) en relación con la duración de la iluminación para una irradiancia incidente constante (Ii).

1979) and macromolecule syntheses (Foy \& Smith, 1980). In order to optimise algal growth in applied mass culture systems, we investigated the effect of day length on the growth rate of three species: Selenastrum minutum, Coelastrum microporum $f$.astroidea and Cosmarium subprotumidum, under various conditions of light/dark photoperiod cycle and irradiance.

\section{MATERIALS AND METHODS}

\section{Source of the organisms}

Three different Chlorophyceaen species were isolated from the eutrophic Takerkoust barrage's 


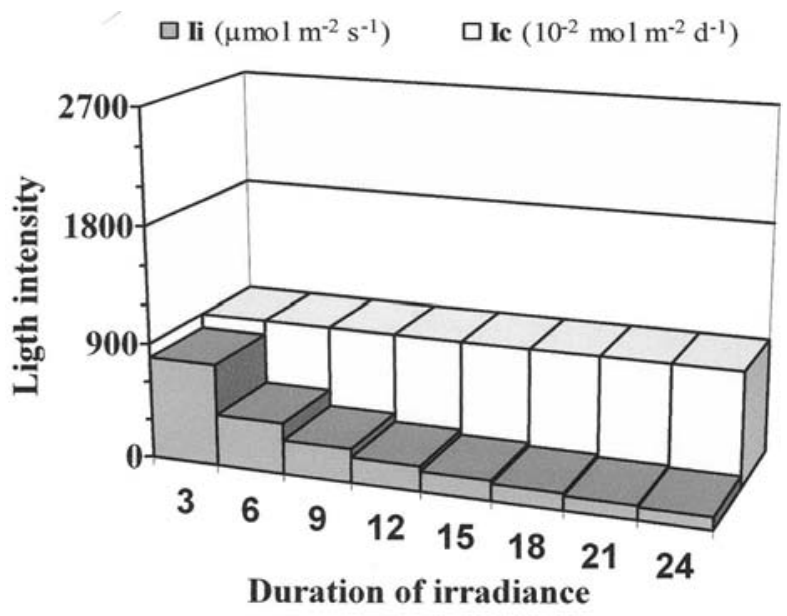

Figure 2. Variation of the incident irradiance (Ii) in relation to the duration of illumination for a constant accumulated irradiance (Ic). Variación de la irradiancia incidente (Ii) en relación con la duración de la iluminación para una irradiancia acumulada constante (Ic).

lake (Western Morocco) and were identified as Coelastrum microporum $f$. astroidea (DENOT) NyG, Selenastrum minutum (Naegeli) Collins and Cosmarium subprotumidum (Nordst) (Philipose, 1967). These species were chosen for our work because they were well adapted to laboratory conditions.

\section{Culture conditions and measurements}

Cultures were unialgal but not axenic. They were grown in batch cultures in a mineral medium (Dauta, 1982) with air bubbling (0.5 1 air $1^{-1} \min ^{-1}$ ) using compressed and filtered air (Whatman filters GF/C of $1.2 \mu \mathrm{m}$ ). Experiments were conducted under controlled light in a temperature-programmable chamber with a 15L/9D photoperiod. Phyto-Claude halogen lamps (400 Watt) were used to illuminate the chamber. The intensity of incident light was measured using a silicon sensor HD 8366. For all the experiments, initial strains were acclimated to the two experimental temperatures $25^{\circ} \mathrm{C}$ and $30^{\circ} \mathrm{C}$ before the experiment was started. In fact, for the two temperatures used, the cultures were maintained in exponential growth by frequent transfers (every 2 or 3 days). A concentrated culture was incubated in the dark for over 24 hours prior
Table 1. Values of the coefficients derived from Belkoura \& Dauta' s (1992) equation for S. minutum, C. microporum and C. subprotumidum. Valores de los coeficientes derivados de la ecuación de Belkoura \& Dauta (1992) para S. minutum, C. microporum $y \mathrm{C}$. subprotumidum.

\begin{tabular}{lccccc}
\hline Species & $A$ & $B$ & $C$ & $D$ & $E$ \\
\hline S. minutum & -2.26 & 0.278 & 0.9 & -1.64 & 0.12 \\
C. microporum & 2.26 & 0.278 & 0.88 & 1.65 & 0.13 \\
C. subprotumidum & -2.26 & 0.276 & 0.98 & -1.7 & 0.12 \\
\hline
\end{tabular}

to the experiment in order to induce synchronization of the algae population and avoid preadaptation to light. A sample of the concentrated culture was diluted in a new medium in order to avoid a self-shading effect. The diluted culture was then distributed among ten flasks and exposed simultaneously to ten different light levels ranging from 30 to $450 \mu \mathrm{mol} \mathrm{m}{ }^{-2} \mathrm{~s}^{-1}$. Experiments (Fig. 1) for the photoperiod's effect were performed at $30^{\circ} \mathrm{C}$ and with an incident light of $300 \mu \mathrm{mol} \mathrm{m} \mathrm{m}^{-2} \mathrm{~s}^{-1}$, under various light:dark cycles $(3 / 21,6 / 18, \ldots 24 / 0, \mathrm{~L} / \mathrm{D})$. This temperature was chosen because the value is quite similar to that of Barrage's lake. This value is effectively characteristic of the three species, which dominate mainly during summer and early fall. However, these experiments don't take into account the accumulated light intensities received by each culture (period of incubation: 24 hours). It was, therefore, not possible to independently appraise the real effect of lengthening light exposure. Therefore, more experiments were carried out (Fig. 2 ), where all cultures under different photoperiod cycles at $30^{\circ} \mathrm{C}$ received the same accumulated irradiance $\left(8.6 \mathrm{~mol} \mathrm{~m}^{-2} \mathrm{day}^{-1}\right)$. The optical density method was used to measure the growth rate at $750 \mathrm{~nm}$ using $1 \mathrm{~cm}$ espectrophotometric cell. This method was chosen because preliminary data showed a significant correlation between cell number and light absorption at 750 $\mathrm{nm}\left(r^{2}=0.99 n=23, r^{2}=0.99 n=27\right.$, $r^{2}=0.92 n=12$ for $S$. minutum, C. microporum and $C$. subprotumidum respectively). The experiment duration was $24 \mathrm{~h}$ for each temperature. Measurements were done at the beginning of the cycle $\left(A_{0}\right)$ and after 24 hours $\left(A_{1}\right)$. The growth rate was calculated; measurements were done at the beginning of the cycle $\left(A_{0}\right)$ and after 24 hours 
$\left(A_{1}\right)$. The growth rate was calculated according to the equation,

$$
\mu=\ln \left(A_{1} / A_{0}\right) \text { day }^{-1}
$$

To estimate physiological parameters for the growth-light intensities relationship, the experimental data were fitted to the model of Peeters \& Eilers, 1978, according to the following equation,

$$
\mu_{(T, 15 / 9)}=\mu_{\max } * 2 *(1+\beta) * I^{\prime} /\left(I^{2}+2 * I^{\prime} * \beta+1\right)
$$

where $\mu, \mu_{\max }$ and $\beta$ are the growth rate, the maximal growth rate and the attenuation coefficient respectively. $I$ and $I_{\mathrm{opt}}$ are the irradiance and optimum irradiance respectively, and $I^{\prime}=I / I_{\text {opt }}$.

Experimental data for the growth and day length relationship was fitted to the model of Belkoura \& Dauta, 1992, according to the following equation,

$$
\mu_{\max _{(30, n H)}}=\mu_{\max _{(30,15 / 9)}}\left[A+1 /\left(B+C \cdot e^{(D-E \cdot n H)}\right]\right.
$$

where $n H$ is the duration of illumination at $T=30^{\circ} \mathrm{C}, A, B, C, D$ and $E$ are not the physiological parameters but the model's coefficients for adjusting the observed data.

The coefficients $(A, B, C, D$ and $E)$ (Table 1 were calculated by the least squares methods. For all experiments, the results are means of three replicate flaks.

Table 2. Main growth parameters of $S$. minutum, $C$. microporum, and C. subprotumidum at $30^{\circ} \mathrm{C}$. Adjusted to the model of Peeters \& Eilers (1978). Principales variables de crecimiento de $\mathrm{S}$. minutum, C. microporum $y$ C. subprotumiduma $30^{\circ}$ C. Ajustadas al modelo de Peeters \& Eilers (1978).

\begin{tabular}{lccc}
\hline Species & $\mu_{\mathrm{max}}\left(d^{-1}\right)$ & $I_{\mathrm{opt}}\left(\mu \mathrm{mol} \mathrm{m}^{-2} \mathrm{~s}^{-1}\right)$ & $G T(\mathrm{~h})$ \\
\hline S. minutum & 1.55 & 365 & 10.7 \\
C. microporum & 1.59 & 390 & 10.4 \\
C. subprotumidum & 0.88 & 360 & 18.9 \\
\hline
\end{tabular}

\section{RESULTS}

The results of the fitted data by Peeters \& Filers's model (equation 2) described in material and methods, are presented in figure 3. The growth rates of the tree species increased with light until they reached a maximum value $\left(\mu_{\max }\right)$ associated with an optimal light intensity $\left(I_{\text {opt }}\right)$. Beyond this intensity, which can be considered as a light saturated growth, $\mu$ decreased more or less rapidly. This photoinhibition occurred at different intensity levels and depended on temperature conditions. The tolerance to light of the algae was higher at a temperature of $30^{\circ} \mathrm{C}$ than at $25^{\circ} \mathrm{C}$.

Table 2 summarizes the main parameters associated with growth of the three species. Generation times (GT) have been determined from $\mu_{\max T}$ (at $T=30^{\circ} \mathrm{C}$ ) using the following relation: $G T=\mu^{-1} \ln 2$ (Reynolds, 1984).

Volumes and surface areas (Table 3) were estimated in order to investigate size effect on the growth rate using a standard geometrical formulae corresponding to an ellipsoid for the three species.

The influence of day length on growth at constant incident light is shown in figure 4. The experimental values indicate an important increase in the growth rate versus day length. A maximum growth for the three species is observed under continuous light ( $S$. minutum: 1.84 day $^{-1} ;$ C. microporum: 1.72 day $^{-1} ; C$. subprotumidum: $1.05 \mathrm{day}^{-1}$ ). On the other hand

Table 3. Volumes (V), Surface areas (SA), and growth rates $\left(\mu_{\max }\right)$ for $S$. minutum, C. microporum and C. subprotumidum. Volúmenes (V), areas superficiales (SA) y tasas de crecimiento $\left(\mu_{\max }\right)$ para $\mathrm{S}$. minutum, C. microporum $y$ C. subprotumidum.

\begin{tabular}{lcccc}
\hline Species & $\mathrm{V}\left(\mu \mathrm{m}^{3}\right)$ & $\mathrm{SA}\left(\mu \mathrm{m}^{2}\right)$ & $\mu_{\max }\left(\mathrm{day}^{-1}\right)$ & $\mu^{*}\left(\mathrm{day}^{-1}\right)$ \\
\hline S. minutum & 19 & 188 & 1.36 & 1.56 \\
C. microporum & 383 & 1091 & 1.16 & 1.27 \\
C. subprotumidum & 1738 & 4270 & 0.74 & 1.12 \\
\hline
\end{tabular}

$\mu_{\max }$, Maximum growth rate obtained from laboratory experiments at $25^{\circ} \mathrm{C}$;

$\mu^{*}$, Maximum growth rate calculated by regression equation of Reynolds (1984) in relation with volume: $\mu=1.855-0.226$ $\left(\log _{10} \mathrm{~V}\right)$. 
the generation time decreased with an increase in irradiance length (Fig. 4).

The influence of day length on growth at constant cumulated irradiance $\left(8.6 \mathrm{~mol} \mathrm{~m}^{-2}\right.$ $\mathrm{day}^{-1}$ ) is shown in figure 5. The results were similar to those observed in figure 4; the growth rate increased with irradiance length; a maximum growth rate for the three species was observed under continuous light (S. minutum: $1.76 \mathrm{day}^{-1}$; C. microporum: 1.88 day $^{-1}$ C. subprotumidum: $\left.1.01 \mathrm{day}^{-1}\right)$. However for the two experiments, after 15 hours of irradiance, the growth rate barely increased and did not change significantly.

\section{DISCUSSION}

The results of the present work show that for a photoperiod of $15 / 9 \mathrm{~L} / \mathrm{D}$, C. subprotumidum exhibited the lowest $\mu_{\max }\left(0.88 \mathrm{day}^{-1}\right)$ at a temperature of $30^{\circ} \mathrm{C}$. Lower growth rate values $\left(0.13-0.33 \mathrm{day}^{-1}\right)$ were reported in some species
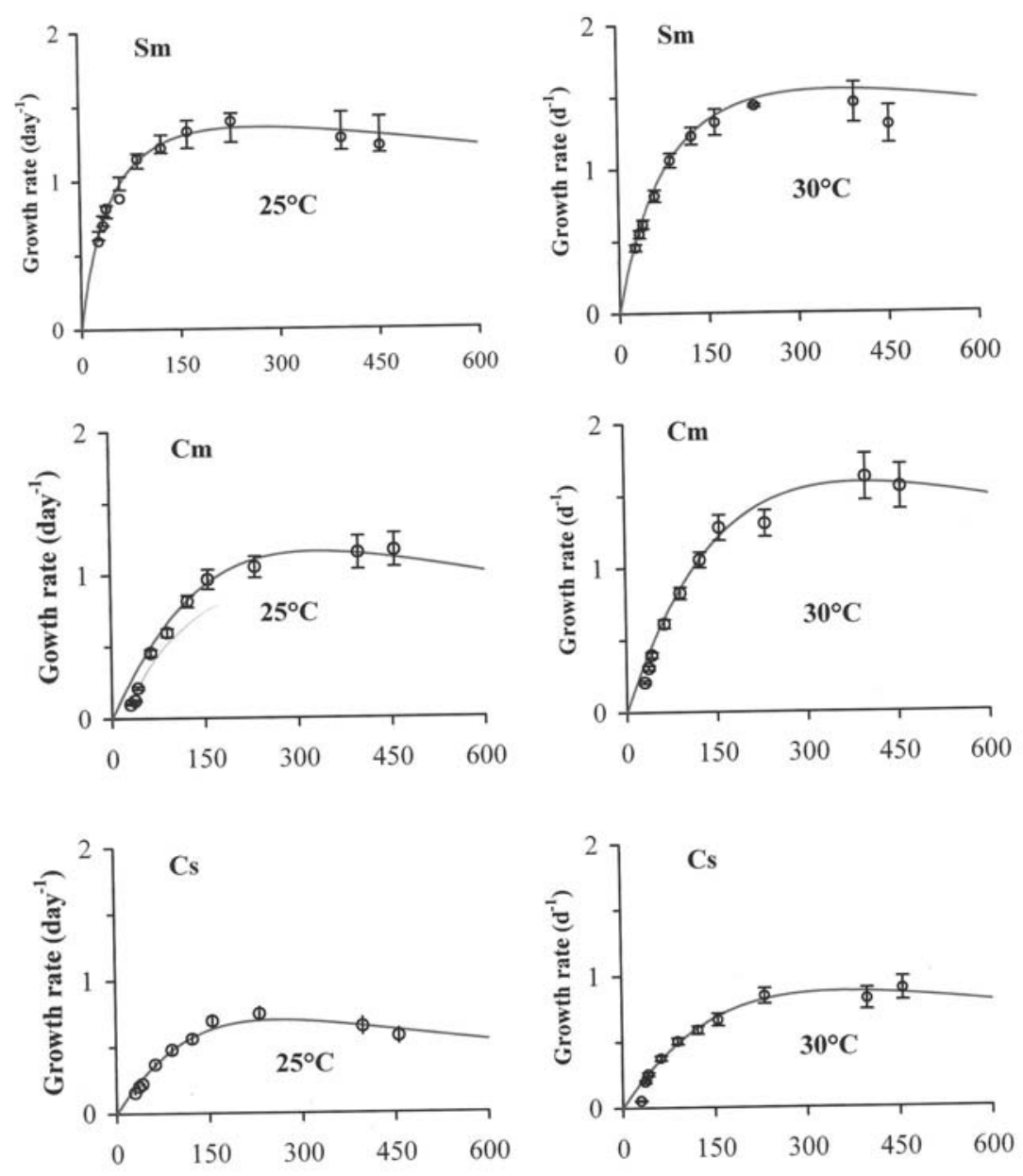

$$
\text { Irradiance }\left(\mu \mathrm{mol} \mathrm{m} \mathrm{m}^{-2} \cdot \mathrm{s}^{-1}\right)
$$

Figure 3. Effect of irradiance on the growth rate for S. minutum (Sm), C. microporum (Cm), and C. subprotumidum (Cs), the observed data $(\bullet)$ are fitted to the function of Peeters \& Eilers (1978) (continuous line). Efecto de la irradiancia en la tasa de crecimiento para S. minutum (Sm), C. microporum $(\mathrm{Cm})$ and C. subprotumidum $(\mathrm{Cs})$, Los datos observados $(\bullet)$ se han ajustado a la función de Peeters \& Eilers (1978) (línea continua). 

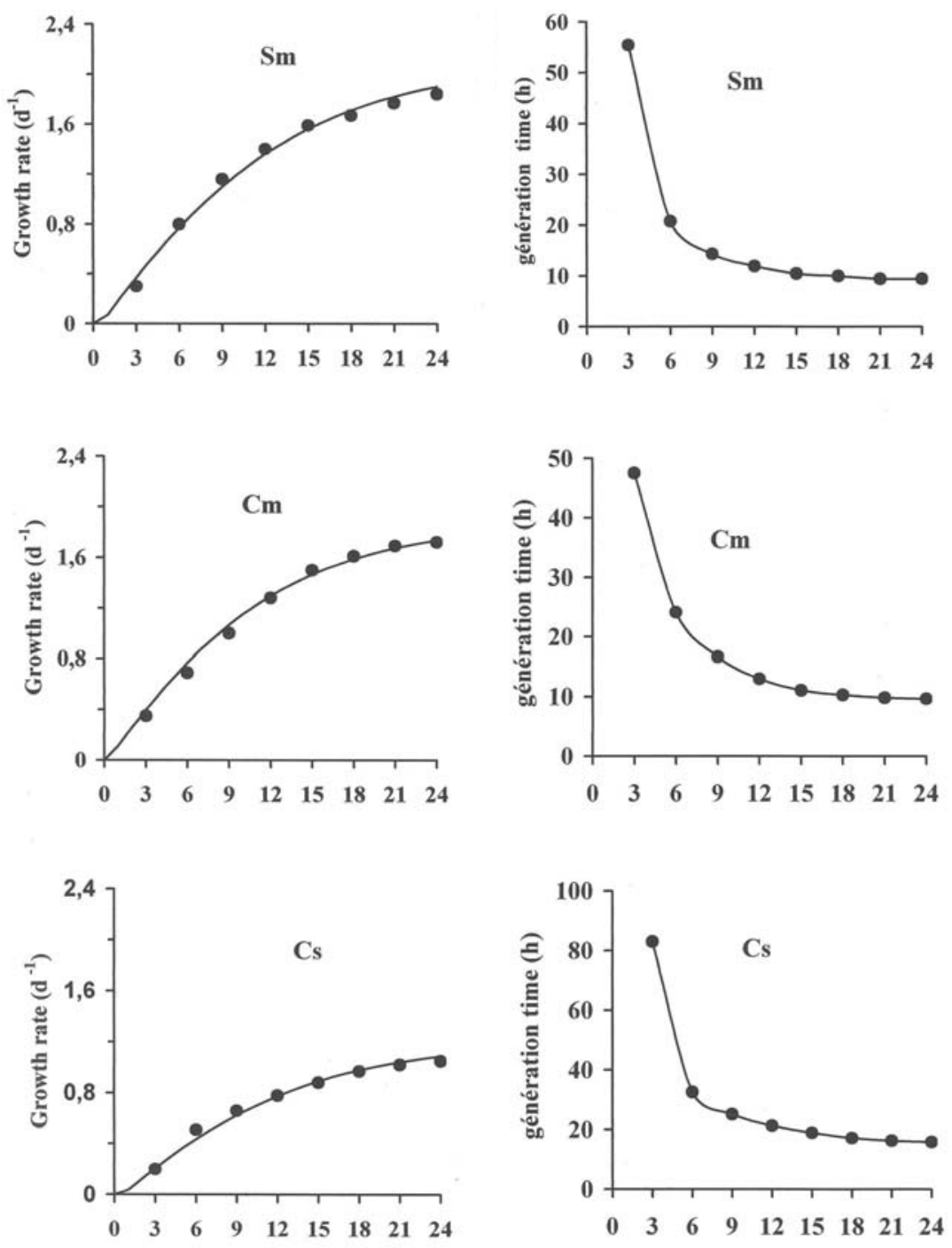

\section{Daylength}

Figure 4. Variation of the growth rate and generation time of $S$. minutum $(\mathrm{Sm})$, C. microporum $(\mathrm{Cm})$, and C. subprotumidum (Cs) in relation to daylength for a constant incident irradiance $\left(I=300 \mu \mathrm{mol} \mathrm{m}^{-2} \mathrm{~s}^{-1}\right)$ at $30^{\circ} \mathrm{C}$. The observed data $(\bullet)$ are fitted to the function of Belkoura \& Dauta (1992) (continuous line). Variación de la tasa de crecimiento y el tiempo de generación de S. minutum (Sm), C. microporum $(\mathrm{Cm})$ y $\mathrm{C}$. subprotumidum $(\mathrm{Cs})$ en relación con las horas diarias de luz para una irradiancia incidente constante $(\mathrm{I}=$ $300 \mu \mathrm{mol} \mathrm{m} \mathrm{m}^{-1}$ ) a $30^{\circ}$ C. Los datos observados (•) se han ajustado a la función de Belkoura \& Dauta (1992) (línea continua).

of desmids (Moss, 1973). Similarly, a lower growth rate $\left(0.5 \mathrm{day}^{-1}\right)$ was found for another desmid species, Staurastrum pingue (Dauta et al., 1990). However, the maximum growth rate $\left(\mu_{\max }\right)$ obtained for $C$. subprotumidum, is lower than those of $S$. minutum and $C$. microporum. The allometric relationship between growth rate and cell size was the most plausible explanation of species' differences in maximum growth rate. Indeed our results indicate that for these species $S$. minutum (smaller size) grew faster than $C$. subprotumidum (larger size). Maximum growth rates of the three species at $25^{\circ} \mathrm{C}$ (Table 3) compared to the predicted values at the same 

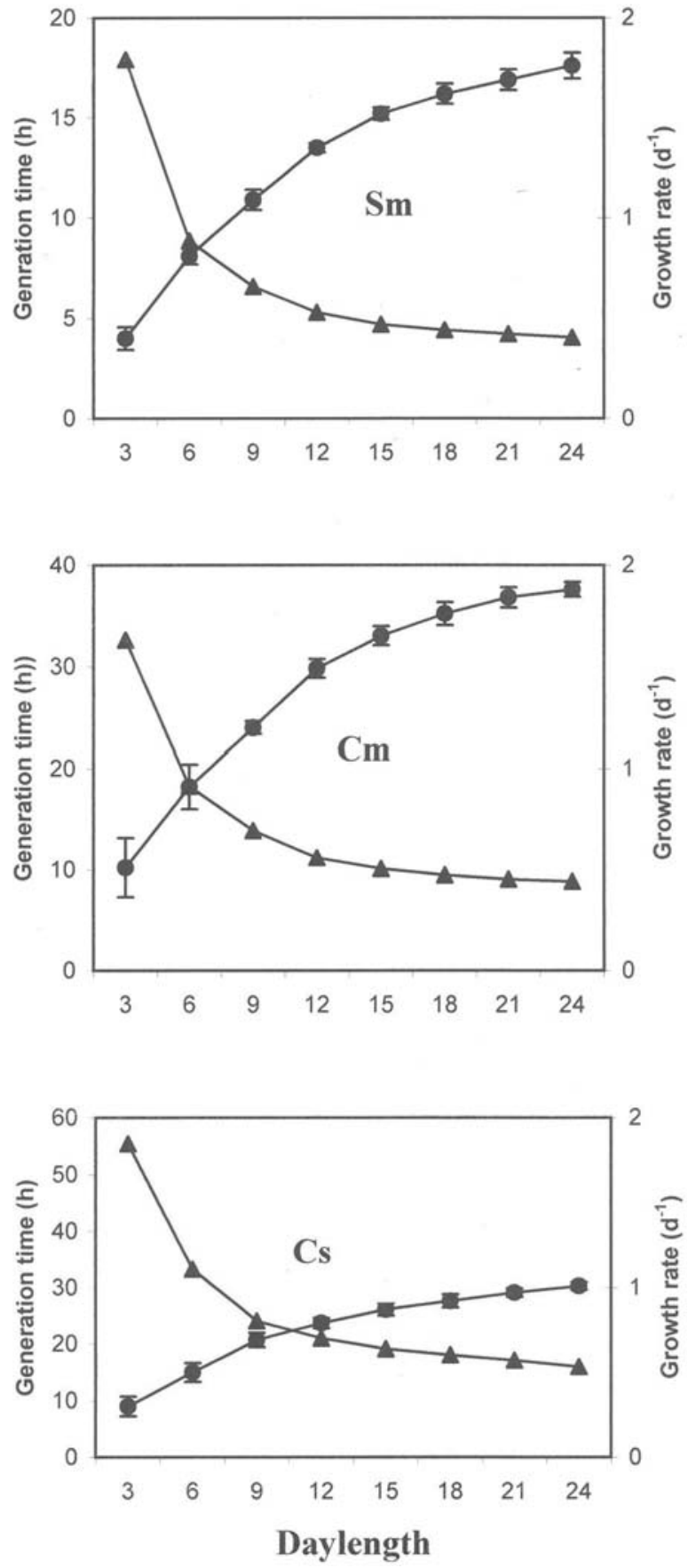

Figure 5. Variation of growth rate and generation time of $S$. minutum $(\mathrm{Sm}), C$. microporum $(\mathrm{Cm})$, and $C$. subprotumidum (Cs) in relation to day length for a constant accumulated irradiance $\left(I=8.6 \mu \mathrm{mol} \mathrm{m} \mathrm{m}^{-2} \mathrm{day}^{-1}\right)$ at $30^{\circ} \mathrm{C}$. Variación de la tasa de crecimiento y del tiempo de generación de $\mathrm{S}$. minutum $(\mathrm{Sm})$, C. microporum $(\mathrm{Cm})$ y C. subprotumidum $(\mathrm{Cs})$ en relación con las horas diarias de luz para una irradiancia acumulada $\left(\mathrm{I}=8,6 \mu \mathrm{mol} \mathrm{m} \mathrm{m}^{-2} \mathrm{dia}^{-1}\right)$ a $30^{\circ} \mathrm{C}$. temperature $\left(25^{\circ} \mathrm{C}\right)$ using Reynolds's equation (1984) were slightly below the regression line. This confirms that our results show an inverse relationship between cell size and growth rate. Similarly, several authors (Foy, 1980; Schlesing et al., 1981; Reynolds, 1984; Stolte et al., 1996) found a significant negative correlation between cell size and growth rate. This is due to the effect of various physiological and metabolic processes as well as the algae size and structure. In fact, small cells assimilate nutrients faster and incorporate carbon more efficiently than large ones (Reynolds, 1984).

Light is an essential resource often limiting the growth rate of algae and is also a major factor determining photosynthetic rate in algae. The optimal light intensity $\left(I_{\text {opt }}\right)$ varied between $360 \mu \mathrm{mol} \mathrm{m}^{-2} \mathrm{~s}^{-1}$ for C. subprotumidum, $365 \mu \mathrm{mol} \mathrm{m}^{-2} \mathrm{~s}^{-1}$ for $S$. minutum, $390 \mu \mathrm{mol} \mathrm{m}^{-2}$ $\mathrm{s}^{-1}$ for $C$. microporum. The growth rate was reduced at light intensity values below or above those ranges. Previous studies revealed that low or high irradiances cannot sustain the maximum growth rate (Ojala, 1993; Belkoura \& Dauta, 1994; Mouget et al., 1995). Beyond the optimal light intensities, the growth seems to be limited by the phenomenon of photoinhibition in the three species. The same results have been observed by other authors (Belkoura \& Dauta, 1992; Lee \& Rhee, 1999; Coles \& Jones, 2000; Benider, et al., 2001).

The influence of day length on the growth rate at a constant incident light $\left(300 \mu \mathrm{mol} \mathrm{m}^{-2}\right.$ $\mathrm{s}^{-1}$ ) show that growth was maximum under continuous light. Accordingly, growth depends on the quantity of energy received by the cultures. The longer the duration of illumination; the shorter cell division is. The accumulated irradiance was indeed a factor that could limit cellular division in S. minutum, C. microporum and $C$. subprotumidum. However, beyond 15 hours of irradiance the variation in growth rate became less and less perceptible, confirming the variation of generation time. In this way, with a 15 hour/9 hour (light/dark) photoperiod cycle the cells seems to have accumulated enough energy for cell division in the closest time to the one observed in continuous culture. Hence, it seems 
that 9 hours of darkness was sufficient for all the phenomena that occur in the absence of light. In this experience, the variation in growth rate could be related to the increase in the accumulated light intensity received during the period of incubation and not to the lengthened irradiance exposure. Therefore, in order to check this hypothesis, a second experiment was carried out, where all cultures received the same accumulated irradiance $\left(8.6 \mathrm{~mol} \mathrm{~m}^{-2} \mathrm{day}^{-1}\right)$. The results show that growth rate is not constant but increased with day length with a maximum at continuous light. These results confirm the real effect of the photoperiod on the microalgae growth rate. A similar response was reported by Nicklish, 1998 and Tahiri, 2000.

The relationship between microalgae growth rate and day length has been a neglected area of study. It is generally considered that algae exhibit a growth rate that is proportional to the duration of the effective light period. Several authors refer to this relationship (Foy 1976, Dermoun, 1987; Nielsen, 1992; Piquemal, 1990; Belkoura \& Dauta, 1992; Foy \& Gibson 1993, Mulyadi 1995).

Cultures under continuous light are often used because they achieve the maximal growth rate recorded. However, most works generally suggest the use of light/dark cycles instead of continuous light, which seems to be inappropriate. Indeed, a light/dark regimen allows for either an increase in final concentration or a lowering of production costs. The necessity of a dark phase was explained by the photosynthesis being governed by two reactions, a photochemical phase that is light dependent and another, a biochemical dark phase that is light independent. The compounds that are produced in the light dependent phase (ATP, NADPH) are used in the dark phase to synthesize metabolic molecules essential for growth. In addition, Laval \& Mazliak (1995) have reported that some enzymes of the pentose cycle of photosynthesis and $\mathrm{CO}_{2}$ fixation are inactive during the illumination. According to Roland \& Joyard (1977), the affinity of carboxydismutase for $\mathrm{CO}_{2}$ decreases dramatically in the dark when the $\mathrm{pH}$ decreases. Its activity can be completely inhibited. This inactivation blocks the uptake of ribulose1,5-diphosphate such as the total uptake could hinder the restarting of photosynthesis in the light. A dark phase remains necessary at least for the regeneration of cofactors $\left(\mathrm{NAD}^{+}\right.$, $\mathrm{NADP}^{+}$) required for phase I of photosynthesis.

With a $15 / 9$ photoperiod cycle, using a series of photographs taken at every hour of the day, Dauta (1982) showed, that cell division occurs under dark conditions for many unicellular Chlorophyceaen. Similarly, Dermoun (1987), working with a $16 / 8$ photoperiod, has shown for Porphyridium cruentum that cell division occurs in the dark phase as well as in the illuminated phase. If the cell equilibrium that mitosis gives is possible under dark and illuminated conditions, cell divisions are more frequent after the interruption of the illuminated phase. It is therefore preferable to use photoperiod with a light duration of between 12 and 15 hours in order to allow for the equilibrium that is established between anabolic and catabolic phenomena during the photoperiod cycle. Furthermore, for industrial applications and considering the ratio between the cost of energy and the corresponding biomass productions, 12 to 15 hours duration for the illuminated phase is generally considered as optimal for algae growth. In addition, the algal species in this work have a natural photoperiod of $15 / 9$ corresponding to the climate of arid and semi-arid regions of the Mediterranean.

\section{REFERENCES}

BELKOURA, M. \& A. DAUTA. 1992. Interaction lumière-température et influence de la photopériode sur le taux de croissance de Chlorella sorokiniana Shihira et Krauss. Annls. Limnol., 28: 101-107.

BELKOURA, M. 1994. Chlorella sorokiniana Shihira et Krauss. Ecophysiologie, modélisation de culture et perspectives de valorisation de la biomasse algale. Thèse de Doctorat d'Etat, Université Cadi Ayyad, Faculté des sciences Semlalia, 154 pp. (+ annexe).

DAUTA, A. 1982. Conditions de développement du phytoplankton. Etude comparative du comporte- 
ment de huit espèces en culture. Annls. Limnol., 18: 217-226.

DE LA NOÜE, J. \& N. DE PAUW. 1988. The potential of microalgal biotechnology : a review of production and uses of microalgae. Biotech. Adv., 6: 725-770.

DERMOUN, D. 1987. Ecophysiologie de Porphyridium cruentum: validation expérimentale d'un modèle de croissance. Etude de la production de polysaccharide. Thèse de Doctorat de l'Université de Technologie de Compiègne, France, 211 pp.

FALKOWSKI, P. G., Z. DUBINSKY \& K. WYMAN. 1985. Growth irradiance relationships in phytoplankton. Limnol. Oceanogr., 30: 311-321.

FOY, R. H. \& C. E. GIBSON. 1993. The influence of irradiance, photoperiod and temperature on the growth kinetic of three planktonic diatoms. Eur. J. Phycol., 28: 203-212.

FOY, R. H. \& R. V. SMITH. 1980. The role of carborhydrate accumulation in the growth of planktonic Oscillatoria species. Br. Phycol. J., 15: 139150.

FOY, R. H., C. E. GIBSON \& R. V. SMITH. 1976. The influence of daylength, light intensity and temperature on the growth rates of planktonic bluegreen algae. Br. Phycol. J., 11: 151-163.

HOBSON, L. A., F. A. HARTLEY \& D. E. KETCHAM. 1979. Effects of variations in daylength and temperature on net rates of photosynthesis, dark respiration and excretion by Isochrysis galbana Parke. Plant. Physiol., 63: 947-951.

LAVAL, D. \& P. M. MAZLIAK. 1995. Nutrition et métabolisme (Physiologie végétale). Ed. Hermann. Paris. 539 pp.

MORRIS, I. 1981. Photosynthetic products, physiological state and phytoplankton growth. In: Physiological bases of phytoplankton ecology. T. Platt (ed.). Can. Bull. Fish. Aquat. Sci., 210: 83-102.

MOSS, B. 1973. The influence of environmental factors on the distribution of freshwater algae: an experimental study. 3. Effects of temperature, vitamin requirements and inorganic nitrogen compounds on growth. J. Ecol., 61: 179-192.

MOUGET, J. L., J. L. DE LA NOÜE, Y. J. LEGENDRE \& P. VIAROUGE. 1995. Long-term acclimatization of Scenedesmus Bicellularis to high-frequency intermittent lighting $(100 \mathrm{~Hz})$. I. Growth, photosynthesis and photosystem II activity. J. Plankton Res., 17: 859-874.
MULYADI, A. 1995. Etude in vitro de la croissance et de la composition biochimique de Porphyridium cruentum aerugineum (Rhodophycees). Implication sur la toxicité cutanée. Thèse de Doctorat. Université Montpellier II. Sciences et techniques du Languedoc. 268 pp.

NIELSEN, M. V. 1992. Irradiance and daylength effects on growth and chemical composition of Gyrodinium aureolum Hulburt in culture. $J$. Plankton Res., 14: 811-820.

NICKLISH, A. 1998. Growth and light absorption of some planktonic cyanobacteria, diatoms and chlorophyceae under simulated natural light fluctuations. J. Plankton Res., 20: 105-119.

OJALA, A. 1993. Effects of temperature and irradiance on growth of two freshwater photosynthetic cryptophytes. J. Phycol., 29: 278-284.

PEETERS, J. C. H. \& P. EILERS. 1978. The relationship between light intensity and photosynthesis: a simple mathematical model. Hydrobiol. Bull., 12: 134-136.

PIQUEMAL, F. 1990. Contribution à l'étude écophysiologique de quelques espèces d'algues en culture. Thèse de Doctorat, Université Paul Sabatier, Toulouse, 137 pp.

REYNOLDS, C. S. 1984. The ecology of freshwater phytoplankton. Cambridge University Press, London: $384 \mathrm{pp}$.

REDALJE, D. G \& E. A. LAWS. 1983. The effect of environmental factors on growth and the chemical and biochemical composition of marine diatoms 1-light and temperature effects. J. Exp. Mar. Biol. Ecol., 68: 59-79.

ROLAND, D. \& J. JOYARD. 1977. Le chloroplaste. La recherche, 79: 527-537.

SCHLESING, D. A. \& L. A. MOLOT. 1981. Specific growth rates of freshwater algae in relation to cell size and light intensity. Can. J. Fish. Aquat. Sci., 38: 1052-1058.

STOLTE, W. \& R. RIEGMAN. 1996. A model approach for size-selective competition of marine phytoplankton for fluctuating nitrate and ammonium. J. Phycol., 32: 732-740.

TAHIRI, M. 2000. Caractéristique écophysiologique et biochimique de l'algue verte Scenedesmus abundans. Influence des conditions de culture. Thèse nationale. Université Cadi Ayyad, Marrakech, Maroc. 91 pp. 
